\title{
EFFECT OF CIRCADIAN RHYTHM AND ENVIRONMENT FACTOR ON THE RISK OF BREAST CANCER: A NEW PATH ANALYSIS EVIDENCE
}

\author{
Anindiya Ningtyas'), Ambar Mudigdo²), Bhisma Murti') \\ ${ }^{1)}$ Masters Program in Public Health, Universitas Sebelas Maret \\ 2)Faculty of Medicine, Universitas Sebelas Maret
}

\begin{abstract}
Background: Breast cancer is the most common type of cancer in women. Disruption of the body's circadian rhythm has been linked to increased risk of breast cancer. This study aimed to examine the effects of circadian rhythm and environment factor on the risk of breast cancer, using path analysis model.

Subjects and Method: A case control study was conducted in Kediri, East Java, from April to May 2018. A sample of 200 women was selected by fixed disease sampling. The dependent variable was breast cancer. The independent variables were work schedule, sleep duration, room light, room temperature, chemical exposure, and air pollution. The data were collected by questionnaire and analyzed by path analysis run on Stata 13 .

Results: The risk of breast cancer increased with irregular work shift $(b=1.76$; $95 \% \mathrm{CI}=0.82$ to $2.70 ; \mathrm{p}<0.001)$, sleep duration $<5$ hours $(\mathrm{b}=1.84 ; 95 \% \mathrm{CI}=0.95$ to $2.73 ; \mathrm{p}<0.001)$, room light on $(\mathrm{b}=1.95 ; 95 \% \mathrm{CI}=0.87$ to $3.02 ; \mathrm{p}<0.001)$, warm room temperature $(b=2.60 ; 95 \% \mathrm{CI}=1.66$ to $3.54 ; \mathrm{p}<0.001)$, air pollution $(\mathrm{b}=$ 2.10; $95 \% \mathrm{CI}=1.16$ to $3.05 ; \mathrm{p}<0.001)$, and chemical exposure $(\mathrm{b}=1.06 ; 95 \% \mathrm{CI}=$ 0.20 to $1.92 ; \mathrm{p}=0.015)$. The risk of breast cancer was indirectly affected by sleep duration and room light.

Conclusion: The risk of breast cancer increases with irregular work shift, sleep duration $<5$ hours, room light on, warm room temperature, air pollution, and chemical exposure. The risk of breast cancer is indirectly affected by sleep duration and room light.
\end{abstract}

Keywords: breast cancer, circadian rhythm, environmental factor

\section{Correspondence:}

Anindiya Ningtyas. Masters Program in Public Health, Universitas Sebelas Maret, Jl. Ir. Sutami No. 36 A, Surakarta 57126, Central Java.

Email: Anindyaningtyas.an@gmail.com. Mobile: +6282232189898 